for me to attend patients immediately on their joining the society, and he also tried to persuade me to make a low uniform charge for each accouchement. I told him that, as far as accouchements were concerned, I should do nothing of the kind. He then remarked to a collector who was with him to the effect that they could not place on my list many enceinte women who might join the society and wish to bo attended by one of their medical officers. As regards immediate attendance, unfortunately for $a$ short time I agreed to it, and the result was that $a$ number of people joined the society for a few weeks in order to get medical attendance and then left it. For those patients, of course, I got no payment whatever, as their names did not appear on the quarterly list. This, Sirs, is what I term "secondary sweating," as it is produced not by fulfilling the terms of agreement with the company, but by its agents. I should like to ask Mr. Woodward if the company approves of such actions on the part of its subordinates; and, if so, what right has the company to ask a medical referee to do more than he has agreed in writing to do? If the superintendents and agents act on their own account, the sooner they are placed under proper control the better, as I know that those who do not agree to the "secondary sweating" have very little chance of wer getting a large list from the company, which, even under the most favourable circumstances, would scarcely pay expenses. I must express my regret that I ever, through gnorance, had any connexion with such a company.

I am. Sirs, yours faithfully,

St. Peter's-park, W., April 29th, $1895 . \quad$ C. W. J. DusLoP.

\section{"THE TITLE OF 'DOCTOR,"}

\section{To the Editors of THE LANCET.}

SIns,-Mr. Cotton's argument is just the converse of mine. Every doctor of medicine is a physician, but every physician is not a doctor, is my contention. A doctorate is a university degree; the possession of a licence in medicine or surgery only makes a man a "Licentiate." The Licentiate of a College of Surgeons is undoubtedly a surgeon, and the Licentiate of a College of Physicians is nndoubtedly a physician; but neither the one nor the other is a graduate in medicine or surgery, not a doctor of medicine or surgery, and not a "doctor" at all in the just and strict professional sense. Mr. Sewell remarks that I suggest "no likely remedy" for the present state of matters. The remedy is surely obvious enough; let men call themselves what they professionally are. The practice of medicine or surgery for gain is not illegal unless a title implying legal qualification is assumed-then punishment can be inflicted. Un the other hand, no matter what legal qualification a man may possess he may call himself "Dr." with impunity. This I hold to be unsatisfactory, to be false representation, and misleading to the public.

$$
\text { I am, Sirs, yours faithfully, }
$$

Glasgow, April 27th, 1895.

D. Campberl BLack.

\section{"MEDICAL CERTIEICATES FOR THE LONDON BOARD SCHOOLS."

$$
\text { To the Editor's of THE LANCET. }
$$

SIRS,-Myattention has been called to an annotation in THH LANCET of April 20th ander the above heading, upon which I shall be obliged if you will kindly allow me to make a few observations. In the first place I may be permitted to state that nothing can be more foreign to the intention of the Board than to put any slight upon the medical profession. With regard to the subject of your annotation it is desirable clearly to define the object of the Board in the proposed appointments, and to set forth the considerations which bave influenced the Board in the matter. In February, 1893, the Board, upon the recommendation of the members ot the Tower Hamlets division, decided to anthorise the appointment of three medical gentlemen in that division to examine cases in which a medical certificate produced by a parent as a reason for the non-attendance at school of his child was considered to be donbtful or unsatisfactory. It had been found that parents who, for one reason or another, desired to keep their children from school frequently presented certificates which were unsatisfactory, either on account of the vagueness of the terms employed or of a doubt as to the seriousness of the malady from which the child was alleged to be suffering. In other cases it was found advisable, for the sake of the child and of the school, to have a definite medical opinion; bat delay and embarrassment arose from the absence of means available for the purpose.

I have before me a report of the Tower Hamlets divisional members upon the result of the experiment up to Jane, 1894. In this report, covering a period of fifteen months, the divisional members state that they consider the results, on the whole, satisfactory, and that they find that the opportunity of obtaining an independent medical examination has had a very beneficial effect in preventing idle excuses of illness and in securing the attendance of children who otherwise would probably have remained out of school. Indeed, the result of the experiment in the Tower Hamlets division has been such that members for other divisions of the metropolis are desirous of adopting a similar plan. I may here remark that the appointments in the Tower Hamlets division were made with the concurrence of the magistrates having jurisdiction in that division, and that appointments which the Board have recently decided to make in the Fast Lambeth division will similarly be submitted to the magistrates having jurisdiction in that division. I would beg to be allowed to point out that the medical certificates which are submitted by parents with regard to the attendance of their children at school are not, as your remarks would seem to imply, given by medical practitioners as a matter of courtesy to the Board. On the contrary, they are procured by the parent for production as evidence of the child's inability to attend school. In conclusion I would venture to remark that, so far from the question of the school attendance of a child being, as you suggest, a "trivial matter," it is, in my opinion, and I think nowadays in the opinion of most people, a matter of vital importance, not only to the fature welfare of the individual child, but also indirectly to the community generally. I am, Sirs, yours faithfully,

JAMAS W. SHARP,

Chairman of the School Accommodation and Attendance Committee.

School Board for London, Victoria-embankment, W.C., April 30th, 1895 .

\section{COVENTRY PROVIDENT DISPENSARY.}

\section{To the Editors of THE LANCET.}

SIRs, - We are glad to be able to inform you that at the annual meeting of the above institution held on Tuesday last the resolution passed in May, 1893--viz , "that the institution being now self-supporting the pecaniary position of an applicant shall be no bar to his admission"-was rescinded. The proposition that it be rescinded was made by the chairman of the committee, seconded by the vice-chairman, and carried by the meeting unanimously. Tnis was the result of the strong representations which we, the staff of the institution, had made to the members at a meeting specially called on account of the position in which the resolution placed us. The result of this is that the institation reverts to the lines on which it has been conducted for over sixty years-viz., that it is an institution for the working classes, and that the names of all applicants for admission are submitted to the monthly meeting of the committee, who exercise their discretion in refusing or accepting them. We send you this information in order that you may be able to let your readers know that we are anxious that our institution should be conducted on principles which are recognised by authorities in our profession. We are, Sirs, yours faithfully,

D. MCVRAGH,

M. FENTON,

Charles Davidson, M.D.,

April 29th, 1895.

. PICKUP. M.D

T. A. HIRD, M.B.

\section{"A PROLONGED CASE OF HICCOUGH." To the Editors of THE LANCET.}

SIRS, - In reading the report of "A Prolonged Case of Hiccough," by Mr. D. Ferguson, I was very much surprised to find no mention made of ol. terebinth being tried, the more so as he had the advantage of consulting three or four 